\title{
Performance Evaluation of Various Geometries of Shear Wall in Buildings by Equivalent Static Judgment
}

\author{
Richa Gupta, Alfia Bano
}

\begin{abstract}
In the present era, tall buildings are very much prominent, therefore its safety against earthquake forces is of vital importance. Shear wall provides an excellent means of resisting the earthquake forces by resisting the lateral force occurring on the building. To provide desired amount of strength and stiffness shear walls are used in the buildings. However, positioning of shear walls requires due consideration both in symmetrical and unsymmetrical buildings. In symmetrical buildings the center of gravity and the centre of rigidity coincide, so that the placement of shear walls is symmetric along the outer edges or inner edges of building. Therefore, it is necessary to find the most ideal and efficient position of shear wall to minimise the effect of torsion. The work presented in this paper focuses on the performance of various geometries of shear wall namely: $C$ shaped, L-shaped, I-shaped, Rectangular-shaped. In this study $G+6, G+16$ and $G+25$ storeyed building is modelled and analysed for lateral displacement, storey stiffness, storey drift using ETABS-2016 software. The analysis of the building is done by using equivalent static method and the results obtained from this method are plotted graphically.
\end{abstract}

Keywords: Rigidity, Storey stiffness, Storey drift, torsion

\section{INTRODUCTION}

Shear wall is vertical plate like RC Walls which starts basically from foundation level and continues to full height of the building. Shear walls is one of the best means of resisting the lateral forces occurring on the multi-storeyed RCC building. Shear walls plays a very important role in earthquake prone areas as the buildings in these areas are more susceptible to damage and destruction. Various factors which influence earthquake design of structure: Ductility of the structure, Type of foundation of the structure, Importance of building, Damping factor of the structure, Natural frequency of the building. Shear wall when in use helps in improving the seismic response of the building since it provides necessary lateral stiffness to resist the lateral load. In tall buildings, columns and beams sizes are bulky and the requirement of Steel is also high. Due to which there is congestion and it is very difficult to place and vibrate concrete and the displacement is also heavy. Therefore, when the shear walls are placed in an advantageous position, they form an efficient lateral force resisting system. In this paper we have generated five different models along with efficient location and geometry of shear wall using ETABS -2016.

Keywords: Ductility, Damping factor, lateral stiffness

Revised Manuscript Received on April 12, 2019.

Richa Gupta, M.Tech. Scholar, Department of Civil Engineering, NIT Raipur, Chhattisgarh (India) (:richa.richa.gupta7@gmail.com)

Alfia Bano, Assistant Professor, Department of Civil Engineering, NIT Raipur Chhattisgarh (India) (alfia.ce@nitrr.ac.in)

\section{Geometry of shear wall}

Shear walls cross-section is oblong i.e. one dimension of the cross-section is larger as compared to the other. As rectangular cross-section is common, $\mathrm{U}$ and $\mathrm{L}$ shaped sections are also used. Thin walled hollow shafts of RC around the elevator core of the building also act as a shear wall.

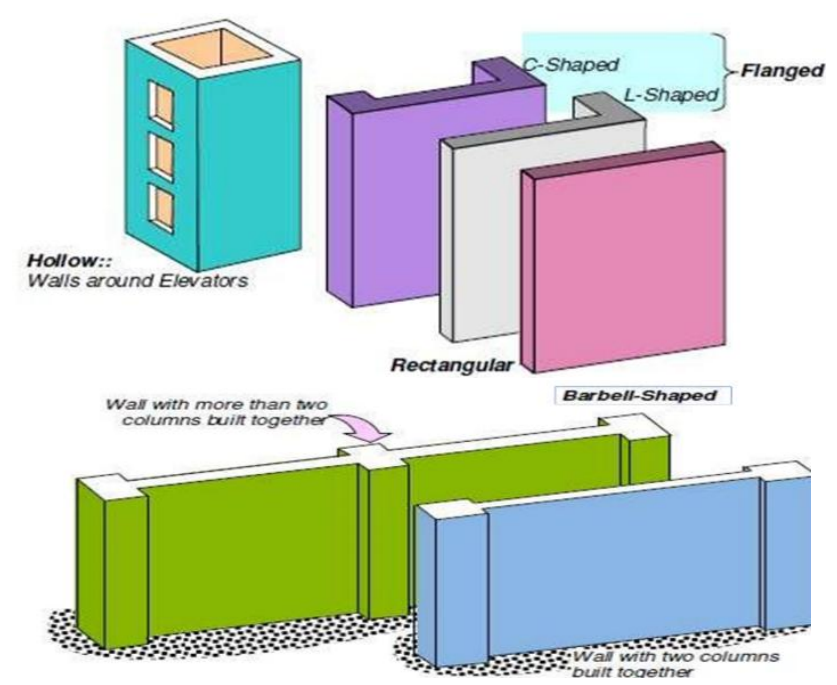

Fig1: Shear Walls in RC Buildings- different geometries are possible

Source: Earthquake tips by C.V.R. Murty,2005

\section{LITERATURE REVIEW:}

Shaik Kamal Mohammed Azam.,2013 [6] focussed on the evaluation of seismic performance of RC framed multistoreyed buildings with shear walls. In this study comparison is being made for strength, stiffness and damping parameters. Using shear walls has a greater effect on lateral strength as compared to the lateral stiffness in tall buildings. In addition to it, shear wall has less effect on lateral strength as compared to lateral stiffness for buildings with shorter heights. The damping characteristics and performance of tall buildings improved by the use of shear walls. In Seismic areas placement of shear wall symmetrically in the outermost frames has better performance in terms of strength and stiffness. MisamAbidi, Mangulkar Madhuri ; 2012 [7] review a shear wall for high rise and given a comparative study for the displacement, base shear and performance point. The assessment of

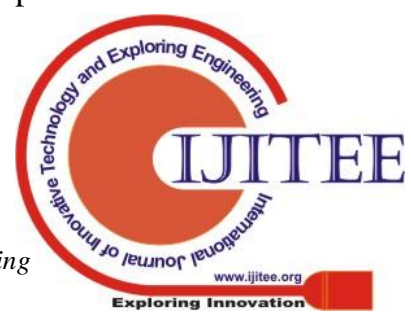


inelastic behaviour has also been done. Shahabodin. ,Zaregarizi ;2013 [8] presented a comparative investigation on seismic performance in areas susceptible for greater collapse by using shear walls and concrete infill walls and his conclusion shows that the performance of concrete infill walls are dependent on nearby elements most importantly columns, that's why premature failure is to be considered in columns due to axial forces. Bozdogan K.B.Deierlein et.al.,2010 [9] discussed regarding the modelling issues along with shear wall structural system using onedimensional finite element method for lateral static and dynamic analysis.

Load Combination: The structure is subjected primary load as per IS Code of practice:

$$
\begin{aligned}
& \text { 1. } 1.2 \mathrm{D} \mathrm{L}+1.2 \mathrm{~L} \mathrm{~L} \\
& \text { 2. 1.2 D L + 1.2 L L + 1.2 E X } \\
& \text { 3. 1.2 D L + 1.2 L L - 1.2 E X } \\
& \text { 4. 1.2 D L + 1.2 L L + 1.2 E Y } \\
& \text { 5. 1.2 D L + 1.2 L L - 1.2 E Y } \\
& \text { 6. } 1.5 \mathrm{DL}+1.5 \mathrm{EX} \\
& \text { 7. } 1.5 \mathrm{DL}-1.5 \mathrm{EX} \\
& \text { 8. } 1.5 \mathrm{D} \mathrm{L}+1.5 \mathrm{E} \mathrm{Y} \\
& \text { 9. } 1.5 \mathrm{D} \mathrm{L}-1.5 \mathrm{E} \mathrm{Y} \\
& \text { 10. } 0.9 \mathrm{DL}+1.5 \mathrm{EX} \\
& \text { 11. } 0.9 \mathrm{DL}-1.5 \mathrm{EX} \\
& \text { 12. } 0.9 \mathrm{D} \mathrm{L}+1.5 \mathrm{E} \mathrm{Y} \\
& \text { 13. } 0.9 \mathrm{D} \mathrm{L}-1.5 \mathrm{E} \mathrm{Y} \\
& \text { 14. 1.2 D L + 1.2 L L + 1.2 W L X } \\
& \text { 15. 1.2 D L + 1.2 L L + 1.2 W L X } \\
& \text { 16. 1.2 D L + 1.2 L L + 1.2 W L Y } \\
& \text { 17. } 1.2 \mathrm{D} \mathrm{L}+1.2 \mathrm{~L} \mathrm{~L}-1.2 \mathrm{~W} \mathrm{~L} \mathrm{Y} \\
& \text { 18. } 1.5 \mathrm{D} \mathrm{L}+1.5 \mathrm{~W} \mathrm{~L} \mathrm{X} \\
& \text { 19. } 1.5 \mathrm{D} L-1.5 \mathrm{~W} \text { L X } \\
& \text { 20. } 1.5 \mathrm{D} \mathrm{L}+1.5 \mathrm{~W} \mathrm{~L} \mathrm{Y} \\
& \text { 21. } 1.5 \mathrm{D} \mathrm{L}-1.5 \mathrm{~W} \mathrm{~L} \mathrm{Y} \\
& \text { 22. } 0.9 \mathrm{D} \mathrm{L}+1.5 \mathrm{~W} \mathrm{~L} \mathrm{X} \\
& \text { 23. } 0.9 \mathrm{DL}-1.5 \mathrm{~W} \mathrm{~L} \mathrm{X} \\
& \text { 24. } 0.9 \mathrm{D} \mathrm{L}+1.5 \mathrm{~W} \mathrm{~L} \mathrm{Y} \\
& \text { 25. } 0.9 \mathrm{D} \mathrm{L}-1.5 \mathrm{~W} \mathrm{~L} \mathrm{Y}
\end{aligned}
$$

Method of analysis: In this study, Equivalent Static Force Method is used for the analysis of the high-rise structure for lateral loads.

\section{Modelling of Structure:}

Salient features of the structure modelled:

\begin{tabular}{clc}
\hline S/No. & Description & Specifications \\
\hline & Building frame & \\
1 & system & SMRF \\
2 & Ground storey height & $3.5 \mathrm{~m}$ \\
8 & Typical storey height & $3.5 \mathrm{~m}$ \\
9 & Type of soil & Medium (II) \\
10 & Support condition & Fixed \\
11 & Grade of concrete & M30 \\
12 & Grade of steel & Fe 415 \\
& & \\
3 & Live load & $2 \mathrm{kN} / \mathrm{m}^{2}$ \\
4 & Floor finish & $1 \mathrm{kN} / \mathrm{m}^{2}$ \\
5 & Importance factor & 1 \\
& Response reduction & 5
\end{tabular}

\begin{tabular}{clc}
7 & Zone & $\mathrm{V}$ \\
13 & Slab thickness & $150 \mathrm{~mm}$ \\
& Thickness of brick & \\
14 & wall & $230 \mathrm{~mm}$ \\
15 & Wind Zone & $\mathrm{V}$ \\
16 & Basic wind speed & $50 \mathrm{~m} / \mathrm{s}$ \\
17 & Terrain Category & III \\
\hline
\end{tabular}

\section{BUILDING MODELLED:}

1. Model 1: Building without Shear Wall.

2. Model 2: Building with L-shaped geometry of shear wall

3. Model 3: Building with rectangular shaped geometry of shear wall

4. Model 4: Building with $\mathrm{C}$ shaped geometry of shear wall

5. Model 5: Building with I shaped geometry of shear wall

Figure 2: Plan of Buildings with various shapes of Shear wall

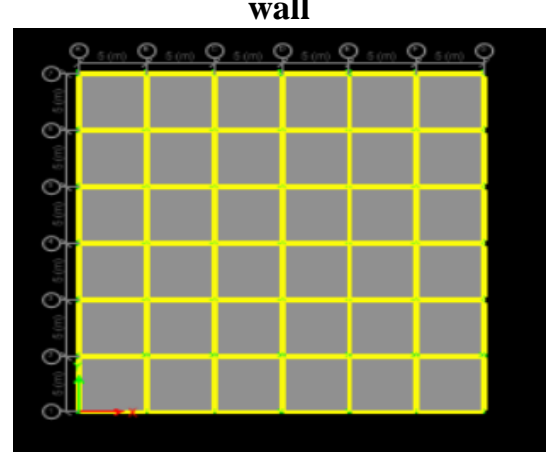

(a) Model 1

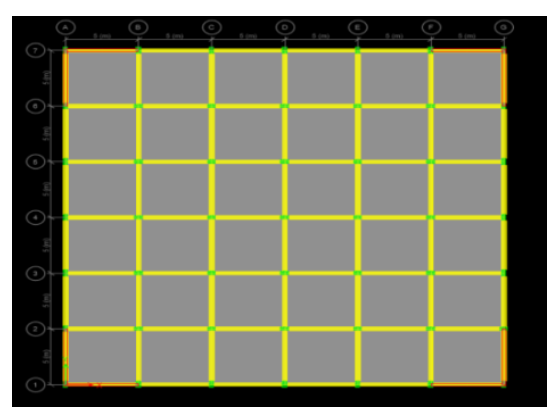

(b) Model 2

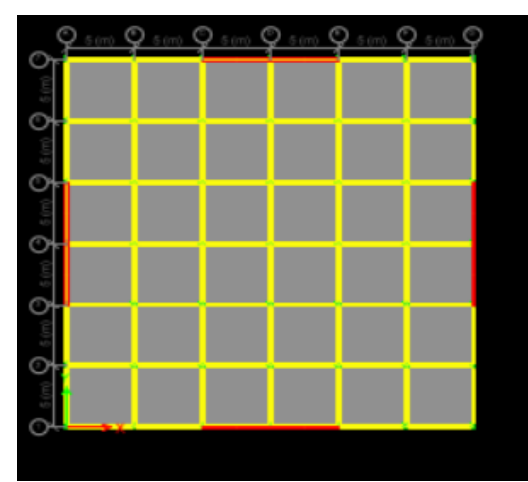

(c) Model 3 
International Journal of Innovative Technology and Exploring Engineering (IJITEE) ISSN: 2278-3075, Volume-8, Issue- 6S4, April 2019

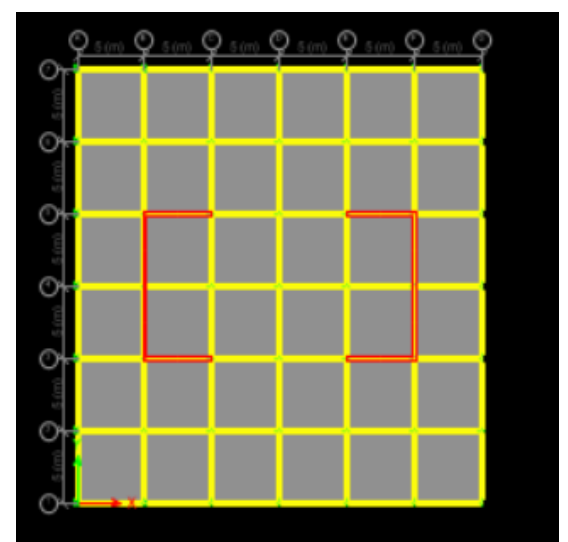

(d) Model 4

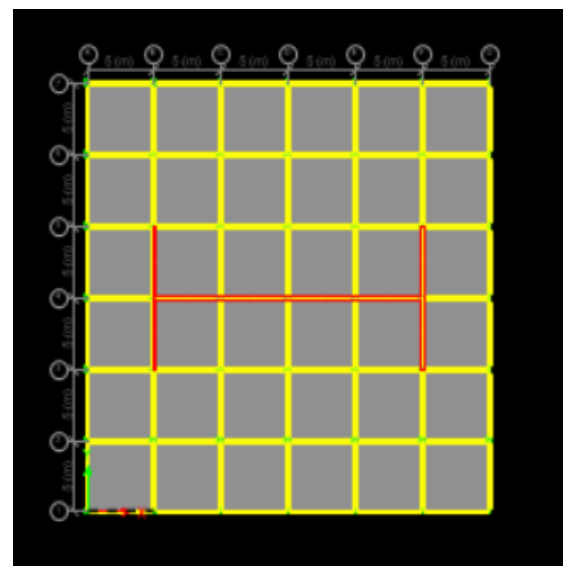

(e) Model 5

Figure 3: 3D view of $\mathrm{RC}$ Building with various shapes of shear wall

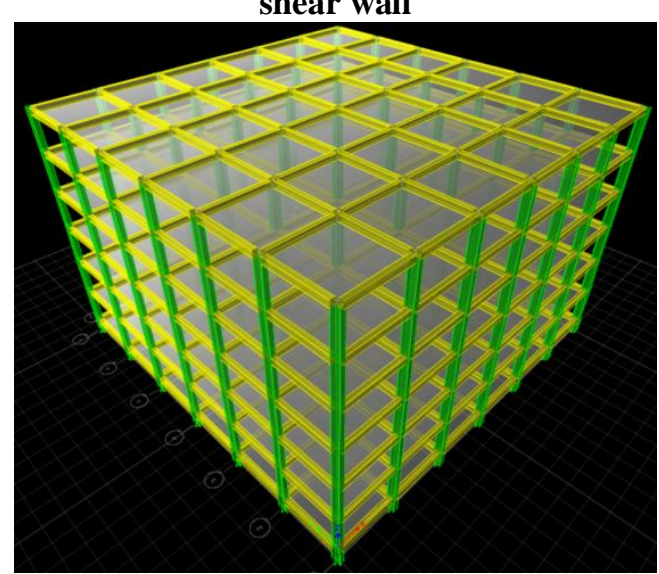

(a) Model 1

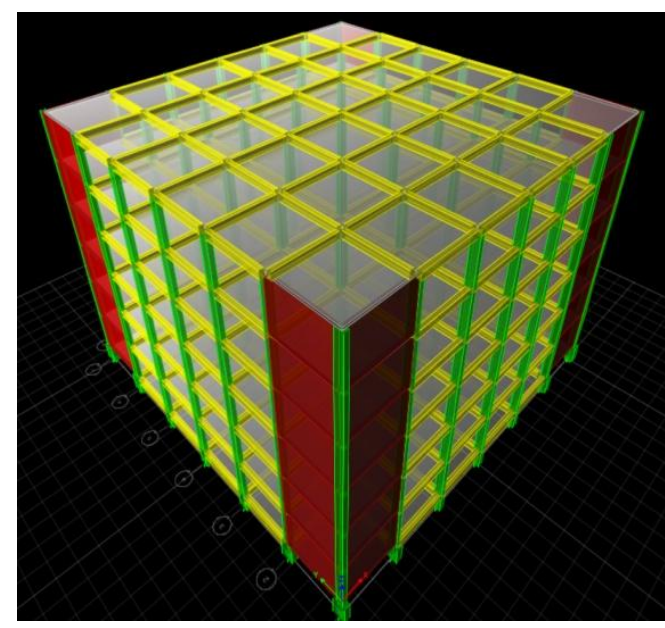

(b) Model 2

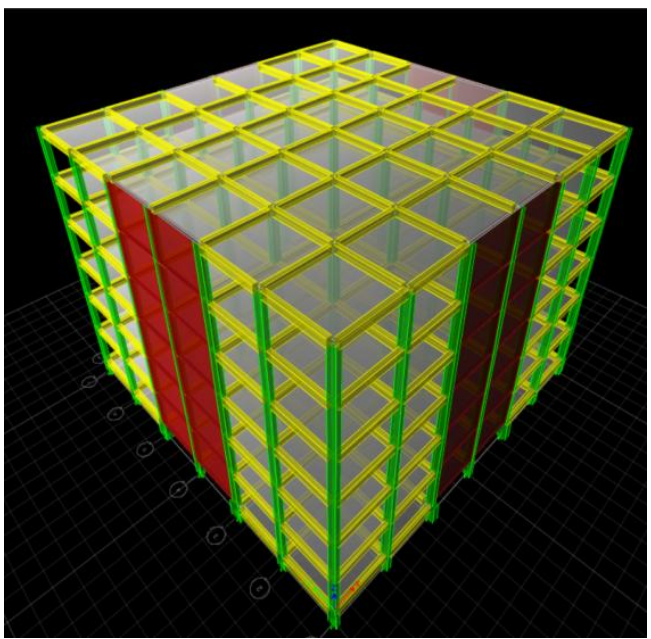

(c) Model 3

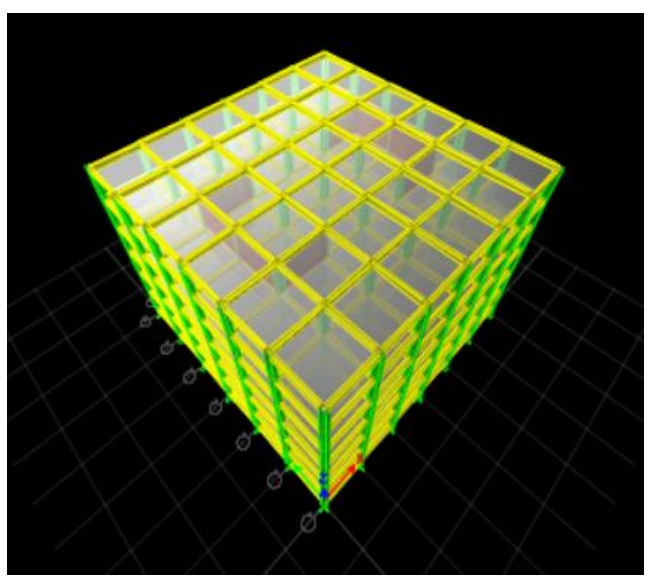

(d) Model 4

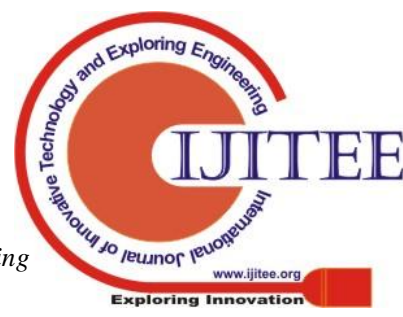




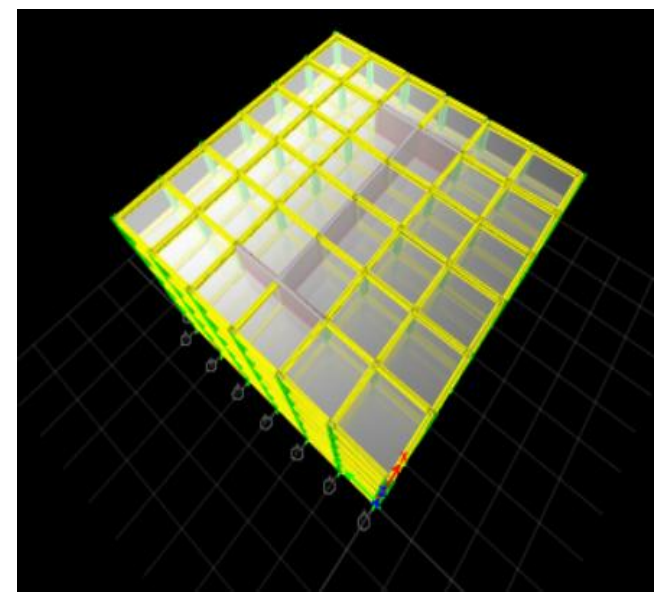

(e) Model 5

IV. MEMBER SIZES OF G+6 STOREY

SALIENT FEATURES OF G+6 STOREY

\begin{tabular}{clc}
\hline SNo. & Description & Specifications \\
\hline 1 & $\begin{array}{l}\text { Column size } \\
\text { (Ground level) }\end{array}$ & $350 \mathrm{~mm} \times 700 \mathrm{~mm}$ \\
2 & $\begin{array}{l}\text { Column size } \\
\text { (other stories) }\end{array}$ & $350 \mathrm{~mm} \times 600 \mathrm{~mm}$ \\
3 & Plinth beam & $400 \mathrm{~mm} \times 550 \mathrm{~mm}$ \\
4 & Beam size & $350 \mathrm{~mm} \times 500 \mathrm{~mm}$ \\
\hline
\end{tabular}

V. MEMBER SIZES OF G+16 STOREY

SALIENT FEATURES OF G+16 STOREY

\begin{tabular}{clc}
\hline SNo. & Description & Specifications \\
\hline 1 & $\begin{array}{l}\text { Column size } \\
\text { (Ground level) }\end{array}$ & $500 \mathrm{~mm} \times 900 \mathrm{~mm}$ \\
2 & $\begin{array}{l}\text { Column size } \\
\text { (other stories) }\end{array}$ & $350 \mathrm{~mm} \times 700 \mathrm{~mm}$ \\
3 & Plinth beam & $450 \mathrm{~mm} \times 700 \mathrm{~mm}$ \\
4 & Beam size & $400 \mathrm{~mm} \times 600 \mathrm{~mm}$ \\
\hline
\end{tabular}

VI. MEMBER SIZES OF G+25 STOREY

SALIENT FEATURES OF G+25 STOREY

\begin{tabular}{clc}
\hline SNo. & Description & Specifications \\
\hline 1 & $\begin{array}{l}\text { Column size } \\
\text { (Ground level) }\end{array}$ & $600 \mathrm{~mm} \times 1000 \mathrm{~mm}$ \\
2 & $\begin{array}{l}\text { Column size } \\
\text { (other stories) }\end{array}$ & $500 \mathrm{~mm} \times 900 \mathrm{~mm}$ \\
3 & Plinth beam & $600 \mathrm{~mm} \times 800 \mathrm{~mm}$ \\
4 & Beam size & $500 \mathrm{~mm} \times 700 \mathrm{~mm}$ \\
\hline
\end{tabular}

Here the results observed for $\mathrm{G}+25$ storeyed building is very much similar with $\mathrm{G}+6 \& \mathrm{G}+16$ storeyed building. In this case also the performance of I shaped geometry shear wall has been better as compared to other geometries of shear wall.

\section{OBSERVATIONS \& RESULTS}

\section{1. $G+6$ building}

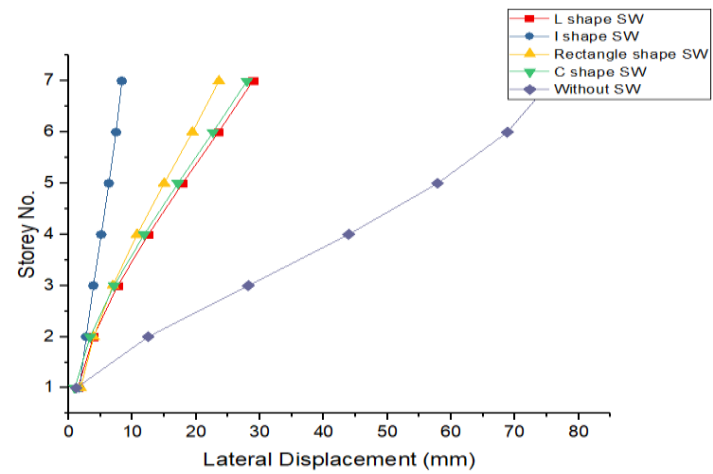

Fig 4: Lateral Displacement vs Storey No.

Here the graph shows the variation of displacement with Storey no. The lateral displacement increases continuously with the increase in storey no, however the amount of displacement observe in I-shaped geometry shear wall is comparatively less as compared to all other geometries of shear wall.

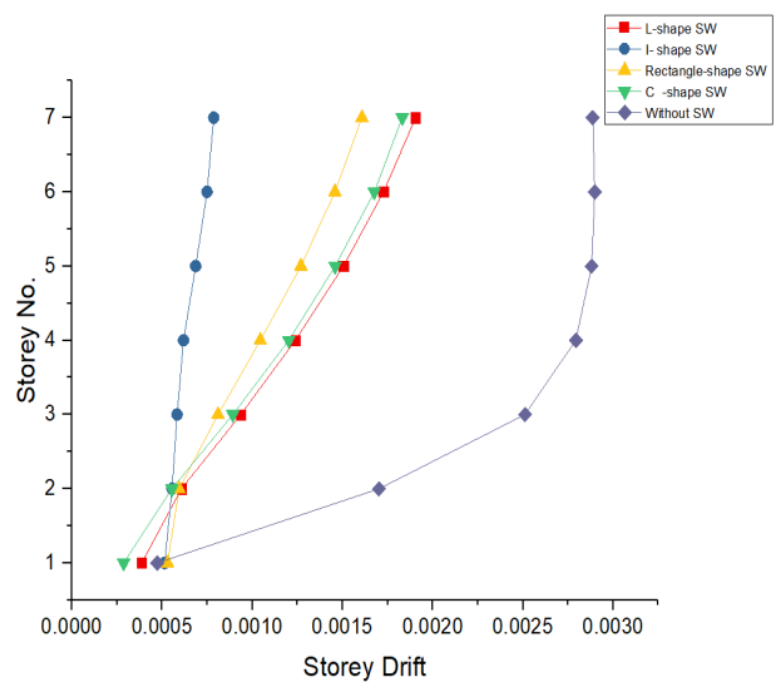

Fig 5: Storey Drift vs Storey No.

The graph shows the variation of Storey Drift with Storey no. Here the drift increases exponentially for various geometry of shear wall but the amount of storey drift observed in I -shaped geometry is very much smaller as compared to all other geometries of shear wall. 


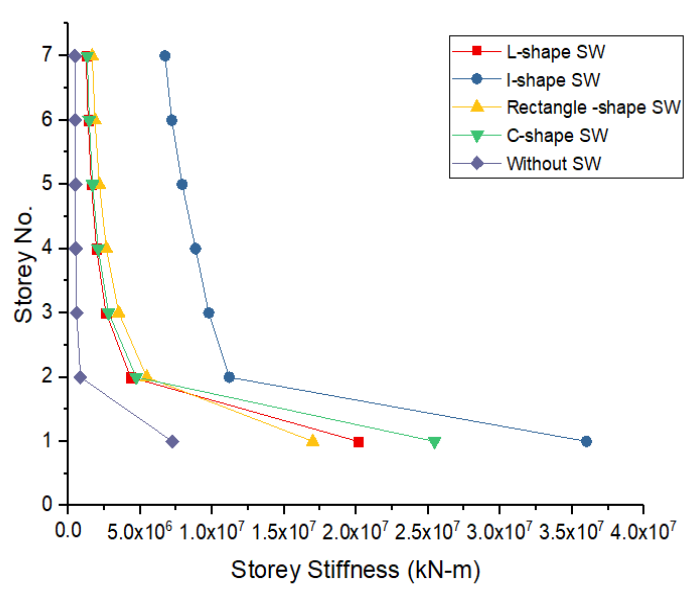

Fig6: Storey Stiffness vs Storey No.

The graph above shows the variation of storey stiffness with Storey no. Here the storey stiffness increases continuously with the increase in storey no., however the level of stiffness observed in I -shaped geometry of shear wall is comparatively more as compared to all other geometries of shear wall.

\section{2. $G+16$ Building}

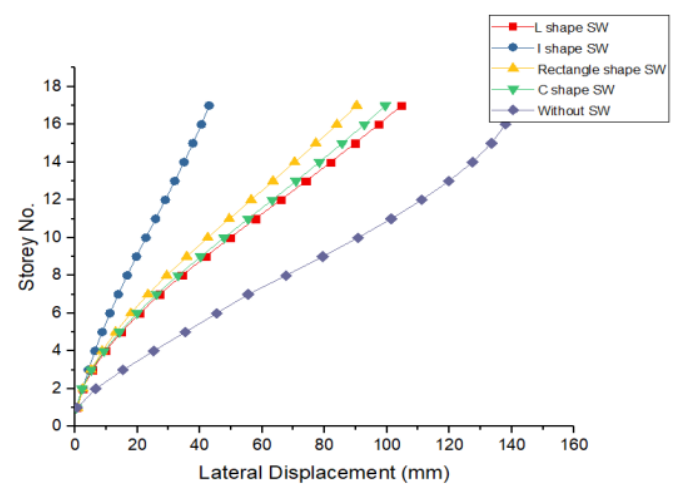

Fig 7: Lateral Displacement vs Storey No.

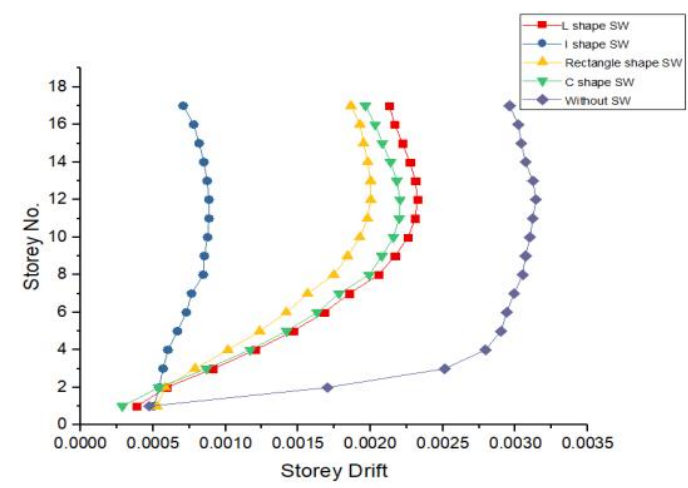

Fig 8: Storey Drift vs Storey No.

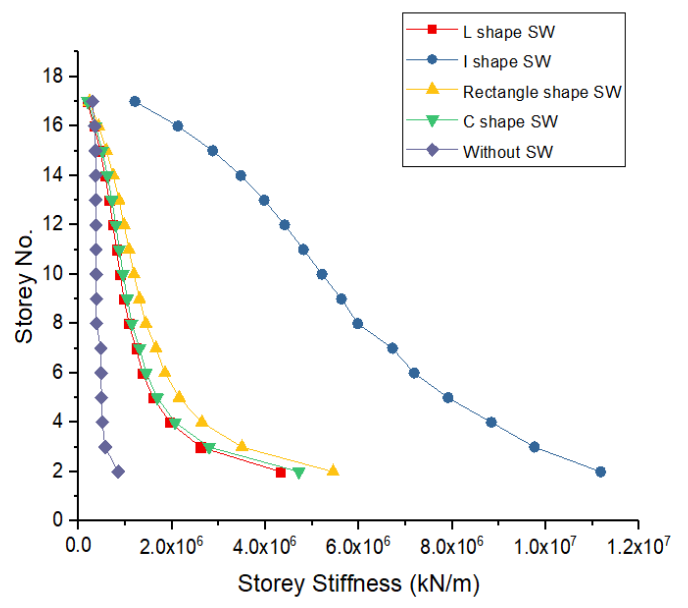

Fig 9: Storey Stiffness v/s Storey No.

\section{3. $G+25$ Building}

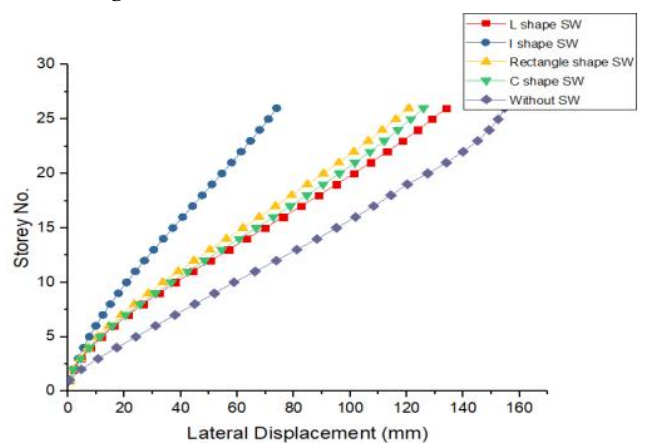

Fig`10: Lateral Displacement vs Storey No

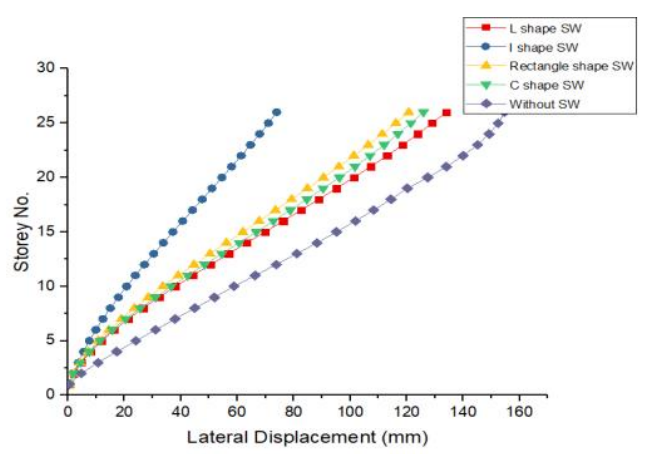

Fig 11: Storey Drift vs Storey No

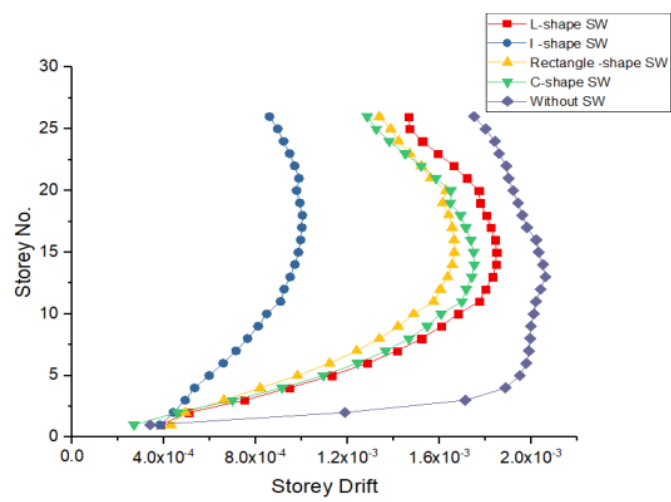

Fig12: Storey Stiffness v/s Storey No 
Here the results observed for $\mathrm{G}+25$ storeyed building is very much similar with $\mathrm{G}+6 \& \mathrm{G}+16$ storeyed building. In this case also the performance of I shaped geometry shear wall has been better as compared to other geometries of shear wall

\section{DISCUSSION}

- For the 3 different types of building it has been observed that there is decrease in the lateral displacement \& storey drift, for the buildings with shear wall when compared with buildings without shear wall. Among the buildings with various shapes of shear wall, the maximum decrease of lateral displacement \& storey drift is observed in building with I -shaped shear wall.

- For the various different types of building it has been observed that there is an increase in storey stiffness for buildings with shear wall when compared with buildings without shear wall. Among the buildings with various shapes of shear wall, the maximum increase in lateral stiffness is observed in building with I -shaped shear wall.

- It has also been observed that considering the effect of wind do not play a significant role in zone 5 for designing a multi storeyed building.

\section{REFERENCES}

1. IS456, "Indian Standard Code of Practice for Plain \& Reinforced Concrete", Bureau of Indian Standards, New Delhi-2000.

2. IS875, "Code of Practice for design loads ( other than earthquake) for building and structures Part II : Imposed loads", BIS, New Delhi 1987.

3. IS1893 Part I - Criteria for Earthquake Resistant Design of Structures”, BIS New Delhi - 2002.

4. IS13920, "Ductile detailing of Reinforced Concrete Structure subjected to seismic forces Code of Practise", 1993.

5. IS875 Part I-V : Code of Practice for structural safety of building loading standards.

6. Mohammad Azam, Shaikh Kamal Hosur Vinod, "Seismic Performance Evaluation of Multi Storeyed RC framed buildings with Shear Wall". International Journal of Scientific and Engineering Research Volume IV, Issue 1, Jan 2013.

7. Abidi Misam, Mangulkar Madhuri, "Review on Shear Wall for soft storey high rise building", International Journal of Civil \& Advance Technology, ISSN 2249-8958, Volume I, Issue 6, Aug 2012.

8. ShahbodinZaregarizi, "Comparative investigation on using shear wall and infill to improve seismic performance of existing buildings", The $14^{\text {th }}$ World Conference on Earth Quake Engineering, Beijing, China, 2008

9. Bozdogan K.B. "A method for lateral static and dynamic analyses of wall framed buildings using 1-D finite elements", Scientific Research \& Essays Vol-VI, pp 616-626, 2011.

10. S K Duggal, “ Earthquake Resistance Design of Structure”, Fourth edition, Oxford University Press, New Delhi 2010.

11. Shrikhande M and Agrawal P, "Earthquake Resistant Design of Structures" PHI New Delhi.

12. Guidelines for Earthquake resistant non engineered construction" IIT Kanpur 2004.

13. S.K Jain and CVR Murthy "Seismic design of reinforced concrete buildings", IIT Kanpur 1999.

14. P.C. Varghese "Advanced Reinforced Concrete Design" $2^{\text {nd }}$ edition by PHI New Delhi ISBN-81-203-2787-X, 2005. 